\title{
Improving Student Assertive Attitude to Reduce Bullying Behavior in Schoool
}

\author{
Ali Rachman \\ University of Lambung Mangkurat \\ Banjarmasin, Indonesia \\ andesmida@gmail.com
}

\begin{abstract}
Bullying at school creates side effect that in shortterm, bullying can create a feeling of unsafe, isolated, low selfesteem, depression or stress until resulting suicide. The objective of the research is to improve student assertive attitude in order to reduce bullying behavior by using counseling group service. Assertive attitude is shown by bravery to tell their mind and their feelings; Also, stand for their right without harming other people. This research is qualitative descriptive research. The result of the research shows there are differences of assertive attitude before and after the implementation of counseling group on students to reduce bullying behavior at school. Based on the result of pairedsample t-test gained significance value as $0.000(p<0.05)$, so the conclusion is student assertive attitude on the posttest, where students assertive data on post-test is higher than student assertive data on the pretest. The implication of research result is bullying behavior could be reduced by improving student assertive attitude on an activity of service using intervention of counseling group.
\end{abstract}

Keywords—counseling group, bullying, assertive

\section{INTRODUCTION}

The study results from National Consortium for Educational Development of Character 2014, showed that there are students bullying cases in every school in Indonesia [1]. $84 \%$ of students have experienced violence at school, $75 \%$ students have committed violence at school and $50 \%$ students reported that they have experienced bullying at school [2].

In Indonesia, some cases of bullying in Senior High School had become society's attention like bullying cases in SMA 90 , SMA 82, SMA 46, SMA 70 and SMA Don Bosco Jakarta. In Banjarmasin there was the attack from a Senior High School to another Senior High School, it causes by negligible reason, students from both schools mock each other because one of the students underestimated by the student from the other school [3]. Another case that happened in Banjarmasin, that a student asks to be transferred to another school because he bullied by his friends until he felt trauma to go to school [4]

Bullying is a purposeful behavior that conducted to pressed, intimidated by frightening the victim to show the strength and power of bullies, less empathy of bullies supports the act of bullying, bullying behavior not only on physical but also on psychological. Bullying at school creates side effect that in short-term, bullying can create a feeling of unsafe, isolated, low self-esteem, depression or stress until resulting suicide. Meanwhile, in long-term, the victim of bullying could have an emotional and behavior problem [5]. Victims usually will feel many negative emotions but they aren't able to face it because they are not accustomed to having assertive behavior toward bullies. More often subject become victim who can't avoid or resist bullying, there will be more often bullying happen so it can be said that student will tend to do or let bullying always happen, even when he does not agree with bullying [6].

The word bullying is used to describe a variety of behaviors that inadvertently be well planned by someone or group of people who have more power toward someone or a group of people who don't have power to against this behavior. The word bullying defines as an individual who disturbs other weak individual and it also means as older children who disturb younger children[7]. Bullying is a deliberate act done to injure and usually oppress the victim, even until the victim feels the need to defend himself. Definition of bullying is a form of physical and psychological violence, done by individual or group to an individual who doesn't able to defend themselves in particular situation or placing that individual under pressures[8].

The act of bullying is a form of behavior that recently became a serious issue. Physically, bullies not only dominated by children who have big and strong physical, children with small or average who have dominant psychological among their friends can also become bullies. The clearest reason why someone become bullies is when bullies feel satisfied if he "in power" among his friends. Bullies actually are children who want more attention, impulsive, dominant as a group, like confrontation and easy to frustrated.

The student becomes a victim of bullying because they seem not able to protect themselves, have weak physical, easy to obey their friends want or have fewer friends. The act of bullying at school is a form of less empathy on bullies and lack of assertive behavior on the student who gets bullied by their friends the highest empathy on teenager the possibility of bullying is getting lower [9].

Studentswhohavebulliedand verbal bullying is the most often happen, factors of friends is one of bullying reason atteenagerage [10]. Commonly students who got bullied is a student who has the low-level of assertiveness [11]. Low level of assertive behavior has much irrational fear, include attitude that showed they worry and don't have the ability to stand for their personal right, so as bullying victim they are not capable to show feeling to against bullying that they get. Because of bullying victim student afraid that bullies will give more bullying. The student who has low-level assertive behavior will have more possibilities of bullying than the student who has high-level of assertive behavior. 
The student with the highest assertive behavior has the lowest possibility become bullying victim [12]. The student with the lowest assertive behavior has the highest possibility become bullying victim. The assertive individual tends to have less conflict with other people. So, in term of bullying assertive individual can avoid bullying. The assertive individual able to conform the social condition around him. Even if there is the individual who able to conform to his social condition because bullying, it should become a concern.

The self-assertiveness as a positive statement that shows appreciation toward other people. An assertive individual usually can create and maintain the close and good relationship with other people. They able to tell their feeling and thought appropriately and honestly without forcing other people. Assertively is able to stand alone, make sure that your opinion and feeling noticed and not letting anyone always get their way [13].

Assertive means with firmness and bravery to state opinion. Assertive behavior is an act of activeness, straightness, and honest [14]. This behavior indicates an impression of respecting themselves and other people so that the individual will see their want, need, and right is same with other people. Or, it could be said as the proper way to act straight, honest, and full of respect when interacted with other people.

Assertiveness as a positive self-statement that show appreciation to other people [15]. Assertiveness defines as a behavior of promoting equality in the social relationship that gives chance for every individual to act base on their selfinterest, defend themselves without worrying, expressing their feeling honestly and pleasantly, and taking personal right without ignoring other people right. Assertive behavior showed an ability to say "no" clearly. Assertive is a behavior that showed braveness to say their need, feeling and thought honestly and openly, stand for personal right, refuse unreasonable request include pressure that comes from authority figure and standard that applied in a group [16]. The definition of assertive is activity or attitude of someone telling their opinion and the real expression without fear and able to communicate with other people fluently. Through assertive behavior, someone can create a good social relationship with his friends, so he will feel valuable and needed by other people, especially emphasize on the interpersonal relationship with the same or different gender.

Able to appreciate the feelings and opinions of others in interpersonal relationships, people who are assertive able to exchange experiences, thoughts, and feelings with others. They accept more positive response and feel understood by others. This thing makes them feel more conform to other people, they will get many advantages like getting the solution and avoided by bullying, get social support and explain mental burden because of the problem. Generally, students who get bullying is a student who has low-level assertive behavior.

Low assertiveness has a lot of irrational fear, include showing anxiety behaviors and do not have the ability to defend the rights of his own. So, do bullying victim they are not able to show their feeling to against bullying because they afraid bullies will give more bullying. Therefore, the student with the low level of assertive behavior, more susceptible to get bullying than the student who has the higher level of assertive behavior. The highest student assertive behavior the lowest possibility become bullying victim [12]. Vice versa, the lowest assertive behavior the highest possibility become bullying victim.

Some characteristics that can be seen from anassertive individual, as follows a) allowing others to explain their thought before himself speaks, b) maintaining a situation that suitable for individual feeling, c) making a decision base on what individual think right, d) seeing a friendship as a chance to learn more about themselves and other people and also to exchanges opinion, e) spontaneously and naturally start a conversation using midin to nation and volume, f) trying to understand other people feeling over their feeling, g) trying to avoid disadvantage and has slething by discussing their problem finding reasonable reason to solve a problem that can't be avoided, h) facing problem and taking decision hardy, and i) taking responsibility for appreciating situation, individual need and right.

Assertive behavior is a form of the pattern (style) of human interaction. As noted by some experts, in relationships or interactions with other people, clients learn to distinguish between aggressive behavior, passive and assertive. Ten keys of assertive behavior, namely: 1) express themselves fully, 2) highly respect the interests of others, 3) directly and firmly, 4) Honestly, 5) they don't picky friends, 6) speak clearly, 7) received socially, 8) listen to others, 9) able to adapt them, 10) always learn better.

Assertive is an ability to communicate what they want, feel and think about other people while maintaining and respecting the rights and feelings of others. The assertive technique is the technique of social skill given to someone who feels anxiety, they can't stand for their right, too weak, letting someone hurting themselves, they can't express their anger with proper way and touchy. Assertiveness affects many aspects of a person's life. Assertive people tend to have fewer conflicts with others. So, the bullying behavior that individuals can prevent the act of bullying.

From several opinions above, it can be said assertively is an ability to communicate what they want, feel and think about other people without anxiety, and keep maintaining and respecting the rights and feelings of others, using positive consideration about attitude and behavior they want to show.

The effort to identify cases of bullying on student soften times meets obstacle [17]. Hidden bullying and victims are not willing or afraid to report bullying which happens on themselves, it causes teachers and parent hard to detect the act of bullying at school. Considering this condition it can be said that bullying is a complex problem that should be solved by the effective solution. A school counselor or guidance and counseling teacher have a role to handle this problem, that by shared commitment between school, parents and counselor (Guidance and Counseling teacher) can reduce the act bullying until more than 50\% [18]. Base on that opinion, so it can be said that school counselor is needed to join in order to help to reduce the act of bullying at school especially through guidance and counseling service at the school. 
Guidance and counseling service at school that mentioned here is counseling service group. Counseling is a process of interpersonal relationship between someone or some counselor with a group of counselee who in that process of interpersonal relationship seeks to help to create and develop counselee ability to face and solve problem or things that become counselee's concern through development of understanding, attitude, belief and appropriate act by using group atmosphere [19].

This research use counseling group as an intervention material to reduce the act of bullying, the rationally counseling group can increase students' assertive behavior. Counseling group can reach domain to reveal behavior aspect more deeply on students. Counseling group is expected to bring up students' assertive behavior as an important part of the process of students' development in building the social relationship with their peer effectively. The importance of counseling group and counseling as a service for meditation and giving a conducive situation for students. Therefore, it can be said that counseling has an important role in reducing the bullying. Counseling group is designed to be able to reduce the bullying at school. Since the intervention of counseling model which is given to the students are expected to give students opportunity to develop themselves in a better direction and also to reach the students' optimal development.

Based on the study result towards some theories of counseling approach, counseling group has main purposes. Such as, to create helping atmosphere between individual which enables every individual develops their own insight and to reach healthier personal adjustment; to emphasize development problems, the engagement of options and values, tend to prevent and heal problems. Counseling group is preventive orientated and also remedial orientated. The group makes a decision, at the beginning of development counseling, it indicates to a process to reach a decision which is agreed by everyone and also involve consensus push and conformity as the addition of the process of reaching the decision.

In group counseling, the group dynamic can be developed well. Therefore, it can support the achievement of service purposes effectively. Counseling group service activates the group dynamic in order to discuss things which are used for individual development and solution for personal problems that are being part of counseling group service. Counseling group service can be applied as game technique whether as interlude or media that consists of certain founding materials. Group orientated work in group counseling; it refers to one kind of group which takes care of one specific problem to be solved, to emphasize the importance of counseling group in developing empathy for people who do the bullying, the people who are being bullied. It is expected to have assertive behavior if they are faced with the certain situation which is lead to an indication to do the bullying, people who do that because they commonly have low empathy to the victims, it happens to those who have no guts to act firmly when people annoy them. Using counseling group, it is expected whether individual or even the people who do bullying can have higher empathy and assertive behavior, so the conformity in the group can emerge. Conformity can help to reduce the chance of bullying if the authority figure, popular or significantly have negative behavior towards bullying, so people around him will also do the same.

Based on the development age, junior high school students who are in the age of teenagers, where they always to feel comfortable with peers. The researcher tries to use the counseling group intervention. Counseling group service as part of the guidance program and counseling at school in helping the students' optimal development, is absolutely need a model in realization agree with the problems that happen at school based on the problem identifications and needs analysis which are obtained from need assessment.

Counseling groups a dynamic process between individual, it focuses on consideration and conscious behavior. Thiskindofprocess has some criteria such as the act of expressing mental emotion and emotion freely, orientated towards the reality, the act of expressing about all of the deep emotions that the person has, trust each other, concern with each other and support each other. Those criteria are created and built between the members of a small group. They share their personal problems and concern to each other and also to the counselor. Counselor basically is classified as normal people who face various kinds of problems which don't need changes in personnel structure to be dealt with. The counselees can also use the personal communication atmosphere in the group to improve understanding and acceptance towards the value of life and all of the life purposes, and also to learn and/or to disappear one characteristic or certain behavior [20].

For students, counseling group can be very useful because through interaction with all of the members they can fulfill some psychologies needs, such as the needs to adapt to their peers and feel accepted by them, they need to share ideas and feelings, the needs of finding life values as something to hold on and the needs of being more independent. In counseling group atmosphere, they may feel it is easier to talk about problems that they face rather in individual counseling, they will accept others opinion or ideas from counselee partners or from the counselors who lead the group rather if they talk to a counselor in counseling individual, they willingly open about what they feel if they watch that there are lots of their partners are not feeling ashamed to talk honestly. They feel more open towards the claim to behave in order to build a better social relationship and feel happier in life because they experience to the full togetherness and unity that is more satisfied with them rather than communication with its own members.

For the counselor, counseling group can be very useful, too. Since the counselor gets some advantages such as the opportunity to observe the behavior of counselee who are doing interaction between each other, to prove himself/herself that he/she is willingly involved in teenagers' life and also participate as the participant in discussion and only as the person who is dominant, to convince the counselee about the usage of counseling service, so the counselee will be interested to continue the relationship with the counselor in individual counseling interview and can serve more people rather than individual counseling. 


\section{METHODOLOGY OF RESEARCH}

This research conducted in SMAN 12 Banjarmasin considering the act of bullying often times happen in this school than other schools. In order to see whether group counseling is effective or not to reduce the act of bullying so researcher conducted counseling group on 12 students, that taken by the purposive sample. This research uses quasiexperiment with one group pretest and posttest design. Every participant gets assertive instrument before and after counseling conducted. Statistic technique use is paired sample t-test

\section{RESULT AND DISCUSSION}

The implication of counseling group on students based on student willingness and commitment to join the activity from the beginning until the end. The activity schedule is not in schooltimes. Soitwon'tdisturbteachingandlearningschedule in school.Data of study result from pre-test and post-test and the difference between pre-test and post-test by using t-test can be seen in table below

TABLE I. RESUlt OF T-TEST AsSERTIVE AsPeCt

\begin{tabular}{|c|c|c|c|c|c|}
\hline \multicolumn{2}{|c|}{} & Mean & $\boldsymbol{N}$ & $\begin{array}{c}\text { Std. } \\
\text { Deviation }\end{array}$ & $\begin{array}{c}\text { Std. Error } \\
\text { Mean }\end{array}$ \\
\hline \multirow{2}{*}{ Pair 1 } & After & 273.75 & 12 & 12.686 & 3.662 \\
\cline { 2 - 6 } & Before & 201.00 & 12 & 14.930 & 4.310 \\
\hline
\end{tabular}

\begin{tabular}{|c|c|c|c|c|c|c|c|c|}
\hline & \multicolumn{5}{|c|}{ Paired Differences } & \multirow{3}{*}{$\mathbf{T}$} & \multirow{3}{*}{ df } & \multirow{3}{*}{$\begin{array}{l}\text { Sig. } \\
(2- \\
\text { taile } \\
\text { d) }\end{array}$} \\
\hline & \multirow[t]{2}{*}{ Mean } & \multirow[t]{2}{*}{$\begin{array}{c}\text { Std. } \\
\text { Deviation }\end{array}$} & \multirow[t]{2}{*}{$\begin{array}{l}\text { Std. } \\
\text { Error } \\
\text { Mean }\end{array}$} & \multicolumn{2}{|c|}{$\begin{array}{c}\text { 95\% Confidence } \\
\text { Interval of the } \\
\text { Difference }\end{array}$} & & & \\
\hline & & & & Lower & Upper & & & \\
\hline $\begin{array}{l}\text { After- } \\
\text { Before }\end{array}$ & 72.750 & 17.838 & 5.149 & 61.416 & 84.084 & 14.128 & 11 & .000 \\
\hline
\end{tabular}

The results of t-test showed that there were differences between assertiveness students before and after the given group counseling, with $\mathrm{t}=14128 \alpha=0.05$, mean 72.750. Based on the analysis of paired samples test above significance value for the assertiveness of $0000<0.05$ or smaller than Alpha0:05, so it can be stated that there were significant differences in the assertiveness of students who take the counseling group. Thus it can be said that the model of group counseling is effective in improving students' assertiveness in reducing bullying behavior in students.

The positive self-statement showed appreciation to other people equally. These facts will not happen without the support of adequate power conformity, an attitude change because of group pressure[20]. The positive vibe from assertive behavior gives strong effect to bullying behavior in counseling group activity. Counseling group, counselee have a chance to listen to each other and paying attention to one and other problem and how to make a decision to solve it[21]. Experiences like this give a positive value to the counselee to learn from the experiences of others, the involvement of individuals in a group can be a force that encourages individuals to be responsible for the behavior and commitments made with members of the group, especially for those who are already involved in a cohesive group, mutual respect and mutual support to each other.

During group counseling service show that individual will realize that bullying is not allowed because it will give negative impact to other people. The appears of assertive behavior when facing bullies. The things remind individual to be able to connect with anyone or able to be accepted and accepting anyone until the feeling of conforming is an individual or group communication. In the manner of counseling group and the experience gained in group dynamics, make students more familiar, more able to accept and appreciate, learn empathy, assertiveness, and also shows good cooperation with friends in group dynamics, in order to tackle bullying in schools, there should be efforts to address bullying that is integrated with group counseling services [22].

\section{CONCLUSION}

Counseling group model is needed in guidance and counseling service at school to reduce the act of bullying by increasing students' assertive behavior. The result of effectiveness test of counseling group on students mainly showed that counseling group can reduce bullying on students is effective. This product effectiveness test supported by data from t-test analysis result or there is differentiated between pretest score and posttest score where the difference in pre-test score and post-test on assertive behavior showed the difference of Alpha 0.05 .

\section{ACKNOWLEDGMENT}

Thanks to the Dean of Faculty of Teacher Training and Education, University of Lambung Mangkurat. Thanks to Guidance and Counseling teachers in SMAN 12 Banjarmasin for all help and support along this research.

\section{REFERENCES}

[1] Herman, "Indonesia Masuk Kategori Darurat Bullying di Sekolah." [Online]. Available: http://www.beritasatu.com/gaya-hidup/219515indonesia-masuk-kategori-darurat-Bullying-di-sekolah.html.

[2] Minister-of-National-Education, Gerakan Penumbuhan Budi Pekerti dan Sekolah Aman. Jakarta, Indonesia, 2015.

[3] Lilis, "Nyaris Tawuran," Banjarmasin Post, Banjarmasin.

[4] "Di Bully, Siswa Trauma Ke Sekolah,” Radar Banjar.

[5] A. B. E. Prasetyo, "Bullying di Sekolah dan Dampaknya bagi Masa Depan Anak," J. El-Tarbawij, vol. IV, no. 1, 2011.

[6] R. Flora, "Mengurangi Perilaku Bullying Kelas X-4 Melalui Pemberian Layanan Bimbingan Kelompok Teknik Role Playing di SMA Negeri 12 Medan Tahun Ajaran 2012/2013," J. Saintech, vol. 6, no. 2, 2014.

[7] H. Shadily and J. M. Echols, Kamus Inggris Indonesia. Jakarta: PT Gramedia Utama, 2003.

[8] T. R. Heald, Judgement in the Case Between R.H. Walker and Derbyshire Country Council. Nottingham: Country Court Records, 1994.

[9] D. H. Karina and Alfiasari, "Perilaku Bullying dan Karakter Remaja Serta Kaitannya dengan Karakteristik Keluarga dan Peer Group,” J. Ilm. Kel. Kons, vol. 6, no. 1, 2013.

[10] M. B. T. Asie, "Studi Deskriftif Perilaku Bullying Remaja," J. Calyptra, vol. 3, no. 1, 2014.

[11] Soendjojo, "Mengajarkan Asertivitas pada Remaja," J. Psikol., vol. 4, no. 3, 2014. 
[12] Novalia and T. Dayasini, "Perilaku Asertif dan Kecenderungan Menjadi Korban Bullying," J. Ilm. Psikol. Terap., vol. 1, no. 1, 2013.

[13] C. Williams, Being Assertive. Glasgow UK: Arnold Publishers, 2001.

[14] S. R. Lioyd, Mengembangkan Perilaku Asertif yang Positif. Jakarta: Binarupa Aksara, 1991.

[15] R. Alberti and M. Emmons, Your Perfect Right. Jakarta: PT.Elex Media Komputindo, 2002.

[16] M. Anindyajati and C. M. Karima, "Peran Harga Diri Terhadap Asertivitas Remaja Penyalahguna Narkoba,” J. Psikol., vol. 2, no. 1, 2004.

[17] A. Basuki, "Preventing School Bullying dengan Media CD." [Online]. Available: http://isjd.pdii.lipi.go.id/admin/jurnal/6210260276_7999.pdf.
[18] I. Saripah, "Model Konseling Kognitif Perilaku Untuk Menanggulangi Bullying Siswa," in Proceeding of 4th International Conference on Teacher Education, Join Conference UPI \& UPSI Bandung, 2010.

[19] R. Natawijaya, Konseling Kelompok Konsep Dasar \& Pendekatan. Bandung: Rizqi Press.

[20] D. G. Myers, Social Psychology. New York: Mc. Grown Hill Book Company, 1991.

[21] Kunandar, Guru Profesional Implementasi Kurikulum Tingkat Satuan Pendidikan (KTSP) dan Sukses dalam Sertifikasi Guru. Jakarta: Raja Grafindo, 2007.

[22] N. A. Wiyani, Save Our Children From School Bullying. Yogyakarta: Ar-Ruzz 